\title{
Genetic parameters for somatic cell score for Polish Black-and-White cattle estimated with a random regression model
}

\author{
E. Ptak ${ }^{1,3}$, P. Brzozowski ${ }^{2}$, W. Jagusiak ${ }^{1}$ and K. Zdziarski ${ }^{2}$ \\ ${ }^{1}$ Department of Genetics and Animal Breeding, Cracov Agricultural University \\ Al. Mickiewicza 24/28, 30-059 Kraków, Poland \\ ${ }^{2}$ Department of Animal Breeding and Production, Cattle Breeding Division, \\ Warsaw Agricultural University \\ Nowoursynowska 166, 02-787 Warszawa, Poland
}

(Received 5 June 2006; revised version 7 May 2007; accepted 6 September 2007)

\begin{abstract}
Genetic parameters for somatic cell score (SCS) for Polish Black-and-White cattle were estimated using 52,599 test day records from the first six lactations of 8,418 cows, and the Bayesian method via Gibbs sampling. The two-trait random regression (RR) model included fixed herd-yearmonth of test effect, fixed regressions within genetic group by age at calving by season of calving subclasses, and random regressions for additive genetic and permanent environment effects. First and subsequent lactations were treated as separate traits. Fourth-order Legendre polynomials were used for regressions. There were 200,000 samples of (co)variances for random effects generated with the first 20,000 samples as the burn-in period.

Genetic variances were in the range of 0.37 to 0.76 throughout first parity and 0.43 to 0.91 throughout later parities, with averages of 0.41 and 0.48 , respectively. Variances for permanent environment increased from 1.04 to 1.37 throughout the first, and from 1.11 to 2.00 throughout subsequent parities. Estimates of heritabilities were from 0.11 to 0.20 for first and 0.13 to 0.22 for subsequent lactations, indicating stronger genetic resistance to mastitis in later parities. The highest values of heritability were observed at peripheries. Genetic correlations for SCS between first and later parities for different days in milk (DIM) were all less than 0.5 , with the highest values in midlactation.
\end{abstract}

KEY WORDS: somatic cell score (SCS), genetic parameters, random regression model, Legendre polynomials

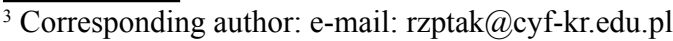




\section{INTRODUCTION}

Mastitis is one of the most frequent and costly diseases in dairy cattle. The high economic losses are mainly due to costs of veterinary treatment but also to decreased milk production, early culling and replacement costs, and lower milk price due to poorer milk quality (Carlén et al., 2004). Dairy producers are interested in finding an effective way to prevent mastitis. Research related to reduction of its incidence through selection has concentrated on the use of somatic cell counts (SCC), which are an indicator of both clinical and subclinical mastitis, and which are easily recorded. The concentration of somatic cells increases significantly in the milk of infected cows. Selecting for fewer somatic cells in milk could significantly improve resistance to mastitis (Schutz, 1994; Charfeddine et al., 1997; Heringstad et al., 2000). However, somatic cells are also present in milk from healthy cows and are an important element in the functioning of the cow's immune system. Research undertaken by Philipsson et al. (1995) examined whether selection for decreased SCC can weaken cows' immunity. The authors concluded that low levels of SCC reflected a reduced incidence of mastitis rather than weakened natural defences.

Many countries have introduced genetic evaluation for milk production traits based on test day (TD) yields (Interbull, 2006). SCC can be analysed with the same TD model as production traits. Before analysis, SCC values must be log-transformed to somatic cell scores (SCS) to meet the assumptions of normality (Ali and Shook, 1980), and knowledge of genetic parameters for SCS is needed. Estimates of heritabilities of SCS ranged from 0.05 to 0.29 , with a tendency to increase with parity (Schutz et al., 1990). Also, estimates of genetic correlations for SCS between lactations have varied considerably, from 0.44 to 1.00 (Shook et al., 1982; Banos and Shook, 1990; Da et al., 1992). Several studies have reported an unfavourable positive genetic correlation between SCS and milk yield traits for first lactation data (Monardes and Hayes, 1985; Schutz et al., 1990), and some authors have reported favourable negative genetic associations between production and SCS in later parities (Pösö and Mäntysaari, 1996; Haile-Mariam et al., 2001a).

The objective of this study was to estimate genetic parameters for SCS in first and subsequent lactations of Polish Black-and-White cattle based on a RR model and using the Gibbs sampling method.

\section{MATERIAL AND METHODS}

\section{Material}

The data file consisted of 52,599 TD records from the first six lactations of 8,418 Black-and-White cows. There were 16,905 and 35,694 SCC data from first and 
subsequent lactations, respectively. It is known from the literature that the same genetic factors influence SCC in second and later parities, so they can be treated as the same trait (Banos and Shook, 1990). Cows were calved from 1998 to 2000 and were the daughters of 319 sires and 5,451 dams. The pedigree file contained 14,145 animals. Only data from cows that calved for the first time between 18 and 48 months of age and TD yields recorded between 5 and 350 DIM were used. The data were grouped in 2,022 herd-year-month of test (HYM) subclasses within first lactations and 4,790 HYM subclasses within subsequent lactations, with at least 4 TD records per subclass. To achieve normality, SCC values were transformed to SCS using the formula: SCS $=\log _{2}(\mathrm{SCC} / 100000)+3$. Simple statistics for SCS are presented in Table 1.

Table 1. Means with standard deviations for SCS within first and later lactations by genetic groups and seasons of calving

\begin{tabular}{|c|c|c|c|c|c|c|c|}
\hline \multirow{2}{*}{\multicolumn{2}{|c|}{ Item }} & \multicolumn{3}{|c|}{ First lactations } & \multicolumn{3}{|c|}{ Later lactations } \\
\hline & & $\mathrm{n}^{1}$ & mean & $\mathrm{SD}^{2}$ & $\mathrm{n}^{1}$ & mean & $\mathrm{SD}^{2}$ \\
\hline \multicolumn{8}{|c|}{ Genetic group } \\
\hline 1 & $\leq 25 \% \mathrm{HG}^{3}$ & 5.056 & 3.17 & 1.79 & 14.273 & 3.96 & 1.99 \\
\hline 2 & $\leq 75 \% \mathrm{HG}$ & 9.606 & 3.06 & 1.77 & 19.547 & 3.76 & 1.96 \\
\hline 3 & $>75 \% \mathrm{HG}$ & 2.243 & 3.12 & 1.81 & 1.874 & 3.44 & 1.88 \\
\hline \multicolumn{8}{|c|}{ Season of calving } \\
\hline 1 & Apr-Sept & 8.584 & 3.12 & 1.75 & 17.465 & 3.89 & 1.91 \\
\hline 2 & Oct-Mar & 8.321 & 3.08 & 1.82 & 18.229 & 3.76 & 2.03 \\
\hline \multicolumn{2}{|c|}{ Total } & 16.905 & 3.07 & 1.79 & 35.694 & 3.78 & 1.98 \\
\hline
\end{tabular}

${ }^{1} \mathrm{n}$ - number of observations

${ }^{2} \mathrm{SD}$ - standard deviation

${ }^{3} \mathrm{HG}$ - Holstein-gene

\section{Model}

The following two-trait RR model was used (Jamrozik and Schaeffer, 1997):

$$
\mathrm{y}_{\mathrm{sijkl}}=\mathrm{HYM}_{\mathrm{si}}+\sum_{\mathrm{m}=0}^{4} \mathrm{~b}_{\mathrm{sjm}} \mathrm{x}_{\text {sklm }}+\sum_{\mathrm{m}=0}^{4} \mathrm{a}_{\text {skm }} \mathrm{x}_{\text {sklm }}+\sum_{\mathrm{m}=0}^{4} \mathrm{p}_{\mathrm{skm}} \mathrm{x}_{\mathrm{sklm}}+\mathrm{e}_{\mathrm{sijkl}}
$$

where: $\mathrm{y}_{\text {sijkl }}$ - the daily SCS of cow $\mathrm{k}$ at $\mathrm{t}_{\mathrm{kl}}$ day in milk in lactation $\mathrm{s}, \mathrm{HYM}_{\mathrm{si}}$ - the fixed effect of the $i$-th herd-year-month of test, $b_{\text {sjm }}$ - fixed regression coefficients within the $j$-th genetic group by age at calving by season of calving subclass, $a_{\text {skm }}$ and $\mathrm{p}_{\mathrm{skm}}$ are random regression coefficients for additive genetic and permanent environmental effects, respectively, and $\mathrm{e}_{\mathrm{sijk}}$ is the random residual effect.

It is known that an RR model with effects of herd test date removed more environmental influences than did the model with effects of herd-year-season (Reents et al., 1995), but because of the data structure in this study only effects 
of HYM can be included in the model. Lactations ( $\mathrm{s}=1$ for first and $\mathrm{s}=2$ for subsequent) were treated as separate traits in the model. Three genetic groups were defined: with $<25 \%$ Holstein genes, with $<75 \%$ Holstein genes and with up to $100 \%$ Holstein genes. Four and nine age groups were created in first and subsequent lactations, respectively, and two seasons of calving (April-September, October-March). The vector of covariates, $\mathrm{x}_{\text {sklm }}$, is defined as a fourth-order Legendre polynomial (Kirkpatrick et al., 1994).

In matrix notation, the model can be written as

$$
\mathbf{y}=\mathbf{X b}+\mathbf{Z}_{\mathbf{1}} \mathbf{a}+\mathbf{Z}_{2} \mathbf{p}+\mathbf{e}
$$

where: $\mathbf{y}$ is a vector of observations, $\mathbf{b}$ includes $\mathrm{HYM}_{\mathrm{si}}$ and $\mathrm{b}_{\mathrm{sim}}$, $\mathbf{a}$ and $\mathbf{p}$ are vectors of additive genetic and permanent environmental random regressions, $\mathbf{e}$ is a vector of random residuals, and $\mathbf{X}, \mathbf{Z}_{1}$ and $\mathbf{Z}_{2}$ are incidence and covariable matrices.

The (co)variance structure was assumed to be

$$
\mathbf{V}\left[\begin{array}{l}
\mathbf{a} \\
\mathbf{p} \\
\mathbf{e}
\end{array}\right]=\left[\begin{array}{ccc}
\mathbf{G} \otimes \mathbf{A} & \mathbf{0} & \mathbf{0} \\
\mathbf{0} & \mathbf{P} \otimes \mathbf{I}_{\mathbf{1}} & \mathbf{0} \\
\mathbf{0} & \mathbf{0} & \mathbf{R} \otimes \mathbf{I}_{\mathbf{2}}
\end{array}\right]
$$

where: $\mathbf{G}$ and $\mathbf{P}$ denote (co)variance matrices of the RR coefficients for additive genetic and permanent environmental effects, each of dimension $10 \times 10, \mathbf{A}$ is the additive genetic relationship matrix among the animals, and $\mathbf{I}_{1}, \mathbf{I}_{2}$ are the identity matrices. $\mathbf{R}$ is the diagonal residual matrix with elements equal to residual variances which depend on DIM (Table 2). The symbol $\otimes$ denotes the Kronecker product.

\begin{tabular}{|c|c|c|c|c|c|}
\hline \multirow{2}{*}{$\begin{array}{l}\text { Error } \\
\text { class }\end{array}$} & \multirow{2}{*}{ DIM $^{1}$} & \multicolumn{2}{|c|}{ First lactations } & \multicolumn{2}{|c|}{ Later lactations } \\
\hline & & mean & $\mathrm{SD}^{2}$ & mean & $\mathrm{SD}^{2}$ \\
\hline $\mathrm{e}_{1}$ & $5-45$ & 1.747 & 0.0985 & 1.756 & 0.0760 \\
\hline$e_{2}^{1}$ & $46-105$ & 1.301 & 0.0476 & 1.507 & 0.0369 \\
\hline $\mathrm{e}_{3}^{2}$ & $106-205$ & 1.148 & 0.0291 & 1.236 & 0.0212 \\
\hline $\mathrm{e}_{4}^{3}$ & $206-305$ & 0.875 & 0.0266 & 0.918 & 0.0190 \\
\hline $\mathrm{e}_{5}^{4}$ & $306-350$ & 0.765 & 0.0660 & 0.501 & 0.0349 \\
\hline
\end{tabular}

Table 2. Estimates of residual variances within first and later lactations

${ }^{1}$ DIM - days in milk

${ }^{2} \mathrm{SD}$ - standard deviation

\section{Estimation of genetic parameters}

The Gibbs sampling algorithm was used to generate 200,000 samples from marginal posterior distributions (Jamrozik and Schaeffer, 1997). There were 120 
(co)variance components generated in each run of iteration (for $\mathbf{G}, \mathbf{P}$ and $\mathbf{R}$ ). The first 20,000 samples were discarded as the burn-in period, and the chain of the remaining 180,000 samples was used for calculations. Means of (co)variances of random regression coefficients for genetic effect are in matrix

$$
\widetilde{\mathbf{G}}=\left[\begin{array}{ll}
\widetilde{\mathbf{G}}_{1} & \widetilde{\mathbf{G}}_{12} \\
\widetilde{\mathbf{G}}_{12} & \widetilde{\mathbf{G}}_{2}
\end{array}\right]
$$

and for permanent environmental effect are in matrix

$$
\widetilde{\mathbf{P}}=\left[\begin{array}{ll}
\widetilde{\mathbf{P}}_{1} & \widetilde{\mathbf{P}}_{12} \\
\widetilde{\mathbf{P}}_{12} & \widetilde{\mathbf{P}}_{2}
\end{array}\right]
$$

where: $\widetilde{\mathbf{G}}_{\mathrm{s}}$ and $\widetilde{\mathbf{P}}_{\mathrm{s}}$ are the $5 \times 5$ matrices of (co)variance estimates of RR coefficients for genetic and permanent environmental effects in first $(\mathrm{s}=1)$ or subsequent $(\mathrm{s}=2)$ lactations, whereas $\widetilde{\mathbf{G}}_{12}$ and $\widetilde{\mathbf{P}}_{12}$ are the $5 \times 5$ matrices of (co)variances between RR coefficients in first and subsequent lactations for both effects (Tables 3 and 4).

Table 3. Estimates of (co)variances between random regression coefficients for genetic effect within

\begin{tabular}{|c|c|c|c|c|c|}
\hline \multirow{2}{*}{\multicolumn{2}{|c|}{ Coefficients }} & \multicolumn{2}{|c|}{ First lactations } & \multicolumn{2}{|c|}{ Later lactations } \\
\hline & & mean & $\mathrm{SD}^{1}$ & mean & $\mathrm{SD}^{1}$ \\
\hline$a_{0}$ & $\mathrm{a}_{0}$ & 0.3074 & 0.0741 & 0.3491 & 0.0673 \\
\hline$a_{0}$ & $a_{1}$ & 0.0212 & 0.0263 & 0.0002 & 0.0225 \\
\hline$a_{0}$ & $a_{2}$ & -0.0177 & 0.0169 & -0.0242 & 0.0177 \\
\hline$a_{0}$ & $a_{3}$ & 0.0061 & 0.0124 & 0.0085 & 0.0128 \\
\hline$a_{0}$ & $a_{4}$ & -0.0053 & 0.0076 & -0.0009 & 0.0069 \\
\hline$a_{1}$ & $a_{1}$ & 0.0577 & 0.0156 & 0.0698 & 0.0144 \\
\hline$a_{1}$ & $a_{2}$ & -0.0131 & 0.0081 & -0.0101 & 0.0075 \\
\hline$a_{1}$ & $a_{3}$ & -0.0007 & 0.0060 & -0.0052 & 0.0056 \\
\hline$a_{1}$ & $a_{4}$ & -0.0001 & 0.0031 & 0.0012 & 0.0029 \\
\hline$a_{2}$ & $a_{2}$ & 0.0273 & 0.0072 & 0.0349 & 0.0073 \\
\hline$a_{2}$ & $\mathrm{a}_{3}$ & -0.0057 & 0.0034 & -0.0042 & 0.0042 \\
\hline$a_{2}$ & $a_{4}$ & -0.0019 & 0.0021 & -0.0036 & 0.0022 \\
\hline$a_{3}$ & $a_{3}$ & 0.0151 & 0.0037 & 0.0220 & 0.0045 \\
\hline$a_{3}$ & $a_{4}$ & -0.0050 & 0.0018 & -0.0079 & 0.0021 \\
\hline$a_{4}$ & $a_{4}$ & 0.0074 & 0.0014 & 0.0078 & 0.0013 \\
\hline
\end{tabular}
first and later lactations

${ }^{1} \mathrm{SD}=$ standard deviation

Genetic variance of SCS on day $i$ in lactation $s$ is estimated as $\mathrm{v}_{\mathrm{gi}}=\mathbf{x}_{\mathrm{i}} \cdot \widetilde{\mathbf{G}}_{\mathrm{s}} \mathbf{x}_{\mathrm{i}}$, and genetic covariance between SCS on days $i$ and $j$ in lactation $s$ is $\mathrm{cv}_{\mathrm{gi}}{ }^{=} \mathbf{x}_{\mathbf{i}} \widetilde{\mathbf{G}}_{\mathrm{s}} \mathbf{x}_{\mathbf{j}}$, where 
$\mathrm{x}_{\mathrm{i}}$ and $\mathrm{x}_{\mathrm{j}}$ are vectors of covariables for days $\mathrm{i}$ and $\mathrm{j}$, respectively. Genetic variance for 350-d lactation yield $\left(\mathrm{v}_{\mathrm{g} 350}\right)$ and covariance between lactations $_{350}\left(\mathrm{cv}_{\mathrm{g} 350}\right)$ are estimated as $\mathrm{v}_{\mathrm{g} 350}=\mathbf{x}_{\mathbf{t}}^{\prime} \widetilde{\mathbf{G}}_{\mathrm{s}} \mathbf{x}_{\mathbf{t}}$ and $\mathrm{cv}_{\mathrm{g} 350}=\mathbf{x}_{\mathbf{t}}^{\prime} \widetilde{\mathbf{G}}_{12} \mathbf{x}_{\mathbf{t}}$, where $\mathbf{x}_{\mathbf{t}}=\sum_{\mathrm{i}=5}^{350} \mathbf{x}_{\mathbf{i}}$. (Co)variances for effect of permanent environment are obtained in a similar way, using matrix $\widetilde{P}$.

Table 4. Estimates of (co)variances between random regression coefficients for permanent environment effect within first and later lactations

\begin{tabular}{lcccccc}
\hline \multirow{2}{*}{ Coefficients } & \multicolumn{2}{c}{ First lactations } & & \multicolumn{2}{c}{ Later lactations } \\
\cline { 2 - 3 } \cline { 5 - 6 } & & mean & $\mathrm{SD}^{1}$ & & mean & $\mathrm{SD}^{1}$ \\
\hline $\mathrm{p}_{0}$ & $\mathrm{p}_{0}$ & 0.9071 & 0.0955 & & 0.9742 & 0.0750 \\
$\mathrm{p}_{0}$ & $\mathrm{p}_{1}$ & 0.0385 & 0.0400 & & -0.0605 & 0.0297 \\
$\mathrm{p}_{0}$ & $\mathrm{p}_{2}$ & -0.1278 & 0.0287 & & -0.0873 & 0.0236 \\
$\mathrm{p}_{0}$ & $\mathrm{p}_{3}$ & 0.0370 & 0.0211 & & 0.0393 & 0.0181 \\
$\mathrm{p}_{0}$ & $\mathrm{p}_{4}$ & -0.0086 & 0.0124 & & -0.0032 & 0.0098 \\
& & & & & \\
$\mathrm{p}_{1}$ & $\mathrm{p}_{1}$ & 0.1951 & 0.0217 & & 0.2237 & 0.0179 \\
$\mathrm{p}_{1}$ & $\mathrm{p}_{2}$ & -0.0137 & 0.0110 & & -0.0093 & 0.0095 \\
$\mathrm{p}_{1}$ & $\mathrm{p}_{3}$ & -0.0370 & 0.0086 & & -0.0528 & 0.0075 \\
$\mathrm{p}_{1}$ & $\mathrm{p}_{4}$ & 0.0044 & 0.0052 & & 0.0152 & 0.0040 \\
& & & & & \\
$\mathrm{p}_{2}$ & $\mathrm{p}_{2}$ & 0.1046 & 0.0122 & & 0.1083 & 0.0103 \\
$\mathrm{p}_{2}$ & $\mathrm{p}_{3}$ & -0.0136 & 0.0064 & & -0.0243 & 0.0059 \\
$\mathrm{p}_{2}$ & $\mathrm{p}_{4}$ & -0.0161 & 0.0039 & & -0.0114 & 0.0031 \\
& & & & & \\
$\mathrm{p}_{3}$ & $\mathrm{p}_{3}$ & 0.0433 & 0.0070 & & 0.0500 & 0.0064 \\
$\mathrm{p}_{3}$ & $\mathrm{p}_{4}$ & -0.0135 & 0.0034 & & -0.0151 & 0.0029 \\
& & & & & 0.0017 \\
$\mathrm{p}_{4}$ & $\mathrm{p}_{4}$ & 0.0154 & 0.0024 & 0.0131 & \\
\hline
\end{tabular}

${ }^{1} \mathrm{SD}$ - standard deviation

\section{RESULTS}

Genetic and permanent environmental variances for SCS in each DIM of first and subsequent lactations were estimated (Figures 1 and 2). Genetic variances were lower in first lactations than in subsequent ones, with mean values of $0.41(\mathrm{sd}=0.056)$ and $0.48(\mathrm{sd}=0.067)$, respectively. The same values of genetic variances were observed between 275 and 315 DIM, and the highest values within the first month after calving in both groups of lactations. In the first parity, genetic variances between 40 and 280 DIM did not change very much (0.37-0.42), and gradually rose thereafter. In later lactations these variances slowly decreased during the second and next months after calving, with little increase after 305 DIM (Figure 1). 


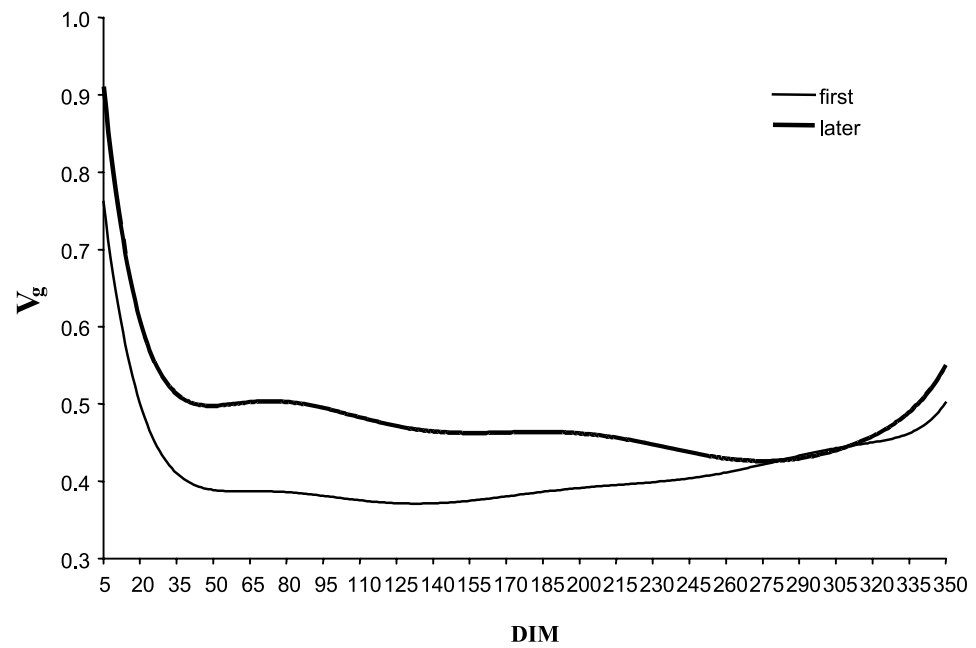

Figure 1. Genetic variances $\left(\mathrm{v}_{\mathrm{g}}\right)$ for somatic cell score (SCS) in 5-350 DIM of first and later parities

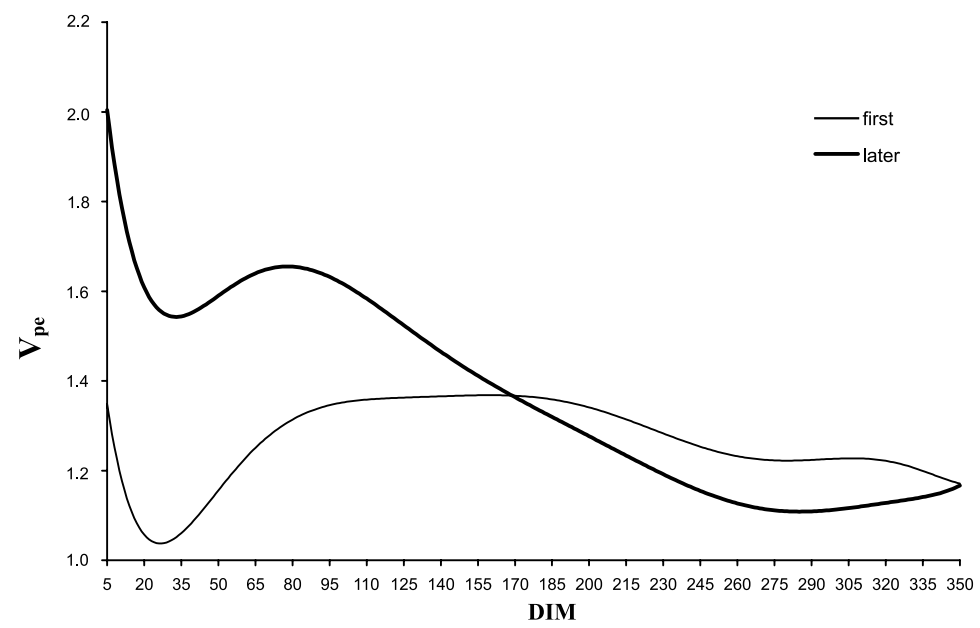

Figure 2. Permanent environmental variances $\left(\mathrm{v}_{\mathrm{pe}}\right)$ for somatic cell score (SCS) in 5-350 DIM of first and later parities

Permanent environmental variances for SCS were higher and more variable than genetic variances during subsequent DIM (Figure 2). The highest variation was observed during the first trimester of following lactations. The first parity estimates were highest in midlactation and during a few days at the very beginning. The permanent environmental variances ranged from 1.04 to 1.37 in the first and from 1.11 to 2.00 in subsequent lactations, with averages of $1.27(\mathrm{sd}=0.091)$ and $1.37(\mathrm{sd}=0.217)$, respectively. During the first five months these variances were 
much lower in the first lactation; during the next months the situation was reversed: permanent environmental variances in subsequent lactations were lower and with smaller daily differences between parities.

Figure 3 presents heritabilities of SCS both in first and subsequent lactations. The $\mathrm{h}^{2}$ values ranged from 0.11 to 0.22 , with means of $0.14(\mathrm{sd}=0.027)$ and 0.15 $(\mathrm{sd}=0.024)$ in the two groups of lactations. They increased slightly from the first

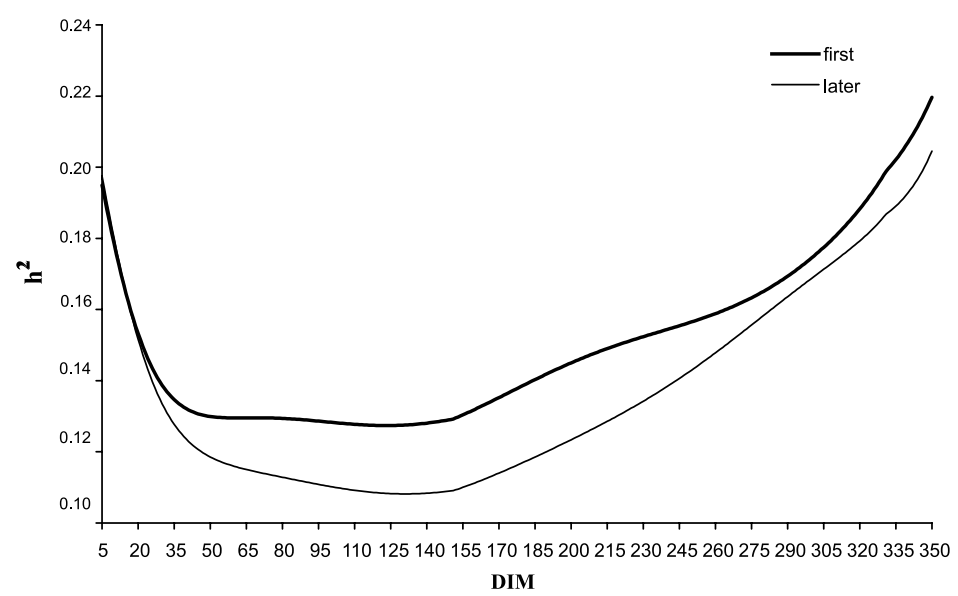

Figure 3. Heritability $\left(\mathrm{h}^{2}\right)$ for somatic cell score (SCS) during first and later parities

to subsequent lactations, except for the first month after calving, during which heritability was the same. Generally, the heritabilities changed throughout the lactations similarly to genetic variances, with the exception of the last 30 DIM when heritability was the highest and genetic variance was not. During the first month after calving, heritability decreased from 0.19 to 0.13 . The lowest $h^{2}$ was observed within the fourth and fifth months of lactation; it rose gradually afterwards, with a rather steep increase after 305 DIM, mainly for later lactations (Figure 3). The high values of heritability at the peripheries could be explained partly by high genetic variation at the beginning and low residual variation at the end of lactation. The heritability of lactation SCS based on TD data was also estimated, giving values of 0.19 and 0.20 for first and subsequent parities, respectively. They were higher than estimates of heritability for daily SCS.

Genetic correlations for SCS between the first and subsequent parities for different DIM are shown in Figure 4. They were rather low in comparison with the genetic correlations for milk yield traits (all less than 0.5), and they depended on the stage of lactation. During the first 20 days after calving the genetic correlations were very low (less than 0.3 ), rising to 0.5 in the middle of the lactation. The genetic correlation for lactation SCS between the first and subsequent parities 


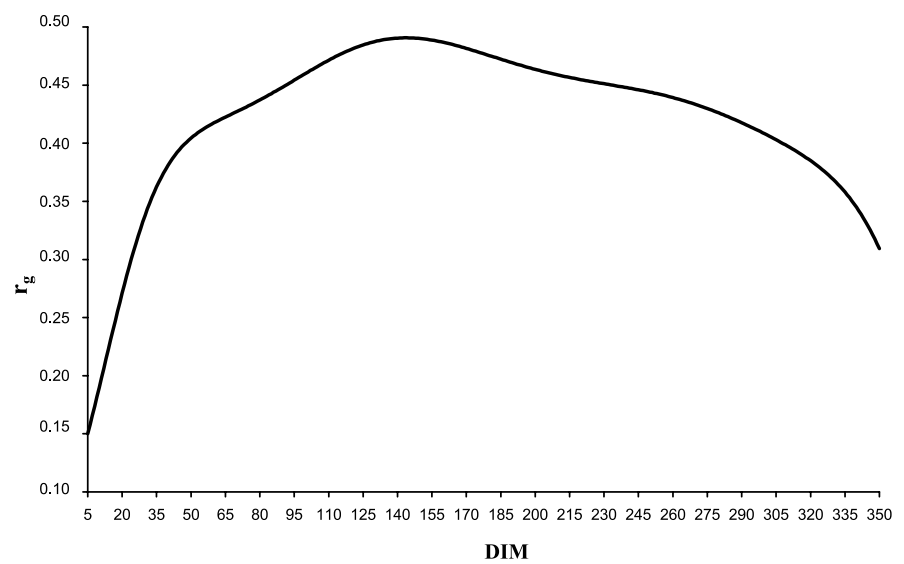

Figure 4. Genetic correlation $\left(\mathrm{r}_{\mathrm{g}}\right)$ between somatic cell score (SCS) of two lactations (first and later) in different DIM

calculated with the use of TD components was moderately high and equal to 0.54 . It was significantly less than unity, so SCSs from first and subsequent lactations should be treated as genetically different traits.

\section{DISCUSSION}

Trends of genetic variances similar to those presented in Figure 1, with the highest values at the beginning of lactation, were presented by Samore et al. (2002) and de Roos et al. (2003). Genetic variances estimated by de Roos et al. (2003) were within a range of values similar to or slightly lower than the genetic variances in this paper. Haile-Mariam et al. (2001b) presented an opposite pattern of changes of genetic variances; they obtained low values at the beginning and higher ones in the second part of lactation, with much lower values (0.04-0.10), but these authors transformed SCC values using a natural logarithm and twoparity RR sire model.

The estimates of permanent environmental variances for SCS presented in this paper (Figure 2) and obtained by Reents et al. (1995) and de Roos et al. (2003) were similar. De Roos et al. (2003) also presented a similar trend of permanent environmental variances for SCS in the first lactation, but in the next two lactations these variances changed differently, resembling the shape of the lactation curve.

Estimates of heritabilities for SCS increased slightly from first to subsequent lactations (Figure 3), in agreement with the results of Schutz et al. (1990), Liu et al. (2001), Samore et al. (2002) and de Roos et al. (2003). In the first parity the estimates of $h^{2}$ varied from 0.11 to 0.20 , and in the later lactations from 0.13 
to 0.22 , showing that genetic resistance to mastitis differed between days/parts of the lactation and was stronger in later parities. This is consistent with earlier findings (Emanuelson et al., 1988; Schutz et al., 1990; Koivula et al., 2004). The high $\mathrm{h}^{2}$ observed at the beginning of both the first and subsequent lactations was due mainly to high genetic variance (Figure 1) and partly to large environmental variation during the early period of lactation (Table 2 ). The decreasing trend observed in estimates of $\mathrm{h}^{2}$ at the beginning of lactation is contrary to the results of Haile-Mariam et al. (2001a), Mrode and Swanson (2003) and Koivula et al. (2004), who reported increasing heritability of SCS towards the end of lactation (from 0.08 to 0.11 ). Liu et al. (2001) obtained fairly homogeneous estimates of $\mathrm{h}^{2}$ for SCS, with an average of 0.09 for first lactation and 0.10 for following (second and third) lactations. The same pattern of homogenous heritabilities was reported in second lactations of Holstein-Friesians (ranging from 0.06 to 0.09 across parity) by Koivula et al. (2004). Many authors have reported lower heritabilities than ours: 0.10-0.15 (Schutz et al., 1990), 0.09-0.11 (Reents et al., 1995), 0.050.12 (Haile-Mariam et al., 2001b), 0.10-0.14 (Carlén et al., 2004), and 0.05-0.12 (Koivula et al., 2004). Some authors obtained $\mathrm{h}^{2}$ ranging from 0.12 to 0.35 in the first three parities (Samore et al., 2002; de Roos et al., 2003). Low heritability for SCS means that limited genetic progress can be made towards decreasing the somatic cell score (Schutz et al., 1990). On the other hand, using SCS as a selection criterion for improving mastitis resistance is more efficient than selecting directly on clinical mastitis data, without considering costs of data collection.

The heritability of lactation SCS estimated based on TD data was higher than estimates for daily SCS. Previous estimates of $\mathrm{h}^{2}$ for the Polish population were lower and decreased with parity: 0.11 for first parity (Reklewski et al., 1998), and 0.14 for first and less than 0.09 for later parities (Sender, 2001). In the literature, estimates of lactation $\mathrm{h}^{2}$ for SCS range from 0.04 to 0.39 (Banos and Shook, 1990; Da et al., 1992; Schutz, 1994; Pösö and Mäntysaari, 1996; Liu et al., 2001). They usually are higher than the heritability of single tests (Shook et al., 1982; Liu et al. 2001; Koivula et al., 2004). They also increase with parity (Monardes and Hayes, 1985; Schutz et al., 1990), although estimates obtained by Sender (2001) and Carlén et al. (2004) showed the opposite tendency, decreasing slightly in subsequent parities (from 0.14 to 0.09). Reents et al. (1995) concluded that heritability estimates of SCS increased with lactation number probably because of the increased frequency of mastitis cases in later lactations, and that it was necessary to include SCS records from later lactations for estimation of breeding values in dairy cattle.

In this paper, the estimates of genetic correlations for SCS on particular DIM between lactations were moderate. Higher estimates (0.48-0.89), with the lowest correlations within the early part of lactation, were reported by Koivula et al. (2004). Liu et al. (2001) obtained correlations of 0.84-0.94 between the first two 
parities, with the biggest estimates in the middle stages of the first and second lactations (0.94) and lower values at the peripheries (0.84). They obtained quite high genetic correlations in the same DIM between the second and third lactations (about 0.95 ), which indicates high genetic similarity between these two parities. This confirmed the assumption made in this study, treating data from the second and following parities as the same trait in the model and estimating (co)variances for SCS. The lower correlations between the first and second lactations, especially at the beginning and end of lactation, showed that SCS in these two lactations were genetically different traits. Banos and Shook (1990) gave culling based mainly on first lactation records as a possible explanation for the moderate correlation between first and later parities.

The genetic correlation for lactation SCS between parities was 0.54 , close to the values obtained by Shook et al. (1982) and Da et al. (1992). In the literature, estimates of genetic correlations for lactation SCS between parities have been contradictory. Banos and Shook (1990) obtained estimates of genetic correlations between first and subsequent parities from 0.71 to 0.81 , and close to 1.00 between second and third parities. Carlén et al. (2004) presented correlations equal to 0.88 and 0.81 between the first and two later parities, and 0.98 between second and third parities. Monardes and Hayes (1985) and Pösö and Mäntysaari (1996) reported even higher genetic correlations among the first three lactations (all greater than 0.9). Reents et al. (1995) obtained estimates higher than 0.79. According to the genetic correlations between the first and subsequent parities, which were significantly different from unity, the SCS values from those lactations should be treated as genetically different traits rather than repeated records of the same trait, whereas the genetic correlation between second and third parities was often around unity, meaning that SCSs from these lactations could be treated as the same trait (Banos and Shook, 1990; Da et al., 1992; Carlén et al., 2004).

\section{CONCLUSIONS}

The genetic parameters for SCS for dairy cattle estimated in this study are in agreement with results from other studies. The heritabilities for SCS are moderate, and little progress can be made toward decreasing the somatic cell score. The genetic correlations between first and subsequent lactations are also moderate, suggesting that genetic evaluation for SCS should be based on TD records from all parities rather than from first ones only. SCS in first and subsequent parities are genetically different traits, and selection in the first lactation may not be sufficiently effective in reducing SCS in later lactations. Accounting for the variation in heritabilities within parity and in the genetic correlations should improve the accuracy of genetic evaluations of dairy cattle for SCS. As suggested 
by many authors and confirmed by the results of this study, in genetic evaluation for SCS it is appropriate to use the multi-trait model with SCSs from first and subsequent lactations treated as different traits, and SCSs within each lactation considered as repeated observations.

\section{REFERENCES}

Ali A.K.A., Shook G.E., 1980. An optimum transformation for somatic cell concentration in milk. J. Dairy Sci. 63, 487-490

Banos G., Shook G.E., 1990. Genotype by environment interaction and genetic correlations among parities for somatic cell count and milk yield. J. Dairy Sci. 73, 2563-2573

Carlén E., Strandberg E., Roth A., 2004. Genetic parameters for clinical mastitis, somatic cell score and production in the first three lactations of Swedish Holstein cows. J. Dairy Sci. 87, 30623070

Charfeddine N., Alenda R., Groen A.F., Carabaño M.J., 1997. Genetic parameters and economic values of lactation somatic cell score and production traits. In: Proceedings of the International Workshop on Genetic Improvement of Functional Traits in Cattle; Health. Uppsala (Sweden). Interbull Bull. 15, 84-92

Da Y., Grossman M., Misztal I., Wiggans G.R., 1992. Estimation of genetic parameters for somatic cell score in Holsteins. J. Dairy Sci. 75, 2265-2271

de Roos A.P.W., Harbers A.G.F., de Jong G., 2003. Genetic parameters of test-day somatic cell score estimated with a random regression model. In: Proceedings of the Interbull Meeting. Rome (Italy). Interbull Bull. 31, 97-101

Emanuelson U., Danell B., Philipsson J., 1988. Genetic parameters for clinical mastitis, somatic cell counts, and milk production estimated by multiple-trait restricted maximum likelihood. J. Dairy Sci. 71, 467-476

Haile-Mariam M., Bowman P.J., Goddard M.E., 2001a. Genetic and environmental correlations between test-day somatic cell count and milk yield traits. Livest. Prod. Sci. 73, 1-13

Haile-Mariam M., Goddard M.E., Bowman P.J., 2001b. Estimates of genetic parameters for daily somatic cell count of Australian dairy cattle. J. Dairy Sci. 84, 1255-1264

Heringstad B., Klemedsdal G., Ruane J., 2000. Selection for mastitis resistance in dairy cattle: a review with focus on the situation in the Nordic countries. Livest. Prod. Sci. 64, 95-106

Interbull, 2006. National Genetic Evaluations Information. http://www-interbull.slu.se/

Jamrozik J., Schaeffer L.R., 1997. Estimates of genetic parameters for a test day model with random regressions for yield traits of first lactation Holsteins. J. Dairy Sci. 80, 762-770

Kirkpatrick M., Hill W.G., Thompson R., 1994. Estimating the covariance structure of traits during growth and ageing, illustrated with lactation in dairy cattle. Genet. Res. 64, 57-69

Koivula M., Negussie E., Mäntysaari E.A., 2004. Genetic parameters for test-day somatic cell count at different lactation stages of Finnish dairy cattle. Livest. Prod. Sci. 90, 145-157

Liu Z., Reinhardt F., Reents R., 2001. Parameter estimates of a random regression test day model for first three lactation somatic cell scores. In: Proceedings of the Interbull Technical Workshop. Verden (Germany). Interbull Bull. 26, 61-65

Monardes H.G., Hayes J.F., 1985. Genetic and phenotypic statistics of lactation cell counts and milk yield and composition of Holstein cows. J. Dairy Sci. 68, 1449-1455

Mrode R.A., Swanson G.J.T., 2003. Estimation of genetic parameters for somatic cell count in the first three lactations using random regression. Livest. Prod. Sci. 79, 239-247 
Philipsson J., Ral G., Berglund B., 1995. Somatic cell count as a selection criterion for mastitis resistance in dairy cattle. Livest. Prod. Sci. 41, 195-200

Pösö J., Mäntysaari E.A., 1996. Relationships between clinical mastitis, somatic cell score, and production for the first three lactations of Finnish Ayrshire. J. Dairy Sci. 79, 1284-1291

Reents R., Jamrozik J., Schaeffer L.R., Dekkers J.C.M., 1995. Estimation of genetic parameters for test day records of somatic cell score. J. Dairy Sci. 78, 2847-2857

Reklewski Z., Philipsson J., Grochowska R., Fikse F., Dymnicki E., 1998. Estimates of genotype by environment effects from milk traits and somatic cell counts among daughters of Swedish Friesian sires in Poland and Sweden. Anim. Sci. Pap. Rep. 16, 197-207

Samore A.B., Boetcher P.J., Jamrozik J., Bagnato A., Groen A.F., 2002. Genetic parameters for production traits and somatic cell scores estimated with a multiple trait random regression model in Italian Holsteins. In: Proceedings of the $7^{\text {nd }}$ World Congress on Genetics Applied to Livestock Production, 26, pp. 63-66

Schutz M.M., 1994. Genetic evaluation of somatic cell scores for United States dairy cattle. J. Dairy Sci. 77, 2113-2129

Schutz M.M., Hansen L.B., Steuernagel G.R., Reneau J.K., Kuck A.L., 1990. Genetic parameters for somatic cells, protein, and fat in milk of Holsteins. J. Dairy Sci. 73, 494-502

Sender G., 2001. Resistance to mastitis as a component of a breeding goal in dairy cattle improving programmes (in Polish). Pr. Mat. Zoot., Special Issue, No. 12, 1-61

Shook G.E., Ruvuna F., Ali A.K.A., 1982. Genetic parameters for lactation average of somatic cell concentration in milk. In: Proceedings of the $2^{\text {nd }}$ World Congress on Genetics Applied to Livestock Production, 8, pp. 142-145 